\title{
Proteolysis of Hispánico Cheese Manufactured Using Lacticin 481-Producing Lactococcus lactis ssp. lactis INIA 639
}

\author{
S. Garde, M. Ávila, P. Gaya, M. Medina, and M. Nuñez ${ }^{1}$ \\ Departamento de Tecnología de Alimentos, Instituto Nacional de Investigación y Tecnología Agraria y Alimentaria (INIA), \\ Madrid, 28040 Spain
}

\begin{abstract}
Hispánico cheese was manufactured using lacticin 481-producing Lactococcus lactis ssp. lactis INIA 639, bacteriocin-nonproducing $L$. lactis ssp. lactis INIA 437, or a combination of both strains, as starter cultures. Lactobacillus helveticus LH 92, a culture of high aminopeptidase activity sensitive to lacticin 481 , was added to all vats. Milk inoculation with the bacteriocin producer promoted early lysis of $L b$. helveticus cells in cheese. Cell-free aminopeptidase activity in cheese made with the 3 lactic cultures was 1.8 times the level reached in cheese made only with $L$. lactis strain INIA 437 and Lb. helveticus, after $15 \mathrm{~d}$ of ripening. Proteolysis (as estimated by the $o$-phthaldialdehyde method) in cheese made with the 3 lactic cultures was twice as high, and the level of total free amino acids 2.4 times the level found in cheese made only with $L$. lactis strain INIA 437 and Lb. helveticus, after $25 \mathrm{~d}$ of ripening. Hydrophobic and hydrophilic peptides and their ratio were at the lowest levels in cheese made with the 3 lactic cultures, which received the lowest scores for bitterness and the highest scores for taste quality.

Key words: lacticin 481, Lactobacillus helveticus, proteolysis, Hispánico cheese
\end{abstract}

\section{INTRODUCTION}

Lactic acid bacteria (LAB) are an important source of enzymes such as proteinases, peptidases, amino acid catabolic enzymes and esterases, which transform milk constituents retained in the curd into low molecular weight compounds (Fox et al., 1996). Because most enzymes produced by LAB are intracellular, cell lysis will favor the access of enzymes to their substrates and presumably will accelerate cheese ripening (Garde et al., 1997; Morgan et al., 1997).

Lysis of LAB cells during early ripening may be enhanced by milk inoculation with bacteriocin-producing

Received April 28, 2005.

Accepted October 26, 2005.

${ }^{1}$ Corresponding author: nunez@inia.es
(BP) adjunct cultures. Thus, Lactococcus lactis ssp. lactis DPC3286, a producer of lactococcins A, B, and M (Morgan et al., 1995), had a bacteriolytic effect on sensitive bacteriocin-nonproducing (BNP) lactococci, increased concentrations of free amino acids, and reduced bitterness in 6-mo-old cheese (Morgan et al., 1997). The combination of an enterocin-producing adjunct culture with a BNP mixed-strain starter culture in the manufacture of a semihard cheese accelerated starter cell lysis and flavor development from d 15 (Garde et al., 1997). Moreover, the levels of nonprotein and amino nitrogen increased significantly in 18- to 42 d-old cheeses when a lacticin 3147-producing $L$. lactis strain was used as starter culture (Martínez-Cuesta et al., 2001). Milk inoculation with L. lactis ssp. lactis INIA 415, a producer of nisin Z and lacticin 481, resulted in accelerated starter cell lysis in Hispánico cheese, which showed higher levels of proteolysis, aminopeptidase activity, free amino acids, and some odor-active volatile compounds, and increased flavor intensity from d 25 of ripening, compared with control cheese (Garde et al., 2002a,b).

The use of highly peptidolytic strains as adjunct cultures in cheese manufacture is another approach for the acceleration of proteolysis during ripening. Strains from some Lactobacillus species, normal constituents of thermophilic starters for varieties such as Parmesan, Mozzarella, and Swiss-type cheeses, present a wide range of peptidolytic enzymes, which can influence flavor development. Comparisons between $L b$. helveticus and other LAB species have demonstrated that $L b$. helveticus strains possess, by far, the highest aminopeptidase and dipeptidase activity levels (Hickey et al., 1983; Sasaki et al., 1995). The results obtained by inoculating milk with highly autolytic $L b$. helveticus strains as adjunct cultures for the manufacture of Cheddar cheese ripened for 8 mo (Hanon et al., 2003) and Swiss cheese ripened for 3 mo (Valence et al., 2000) suggest a correlation of adjunct lysis with increased proteolysis and accelerated flavor development.

Addition of a $L b$. casei strain and a nisin-producing culture in the manufacture of Cheddar cheese, monitored over a 6-mo ripening period, produced a debittering effect and improved flavor quality (Benech et al., 
2003). Furthermore, a nisin-producing L. lactis ssp. lactis strain, combined with a highly autolytic and proteolytic $L b$. delbrueckii ssp. bulgaricus strain and with 2 BNP L. lactis strains, increased the levels of watersoluble nitrogen, free amino acids, free fatty acids, and flavor in Cheddar cheese ripened for 6 mo with respect to cheese made without BP (Sallami et al., 2004a,b).

In the present work, L. lactis ssp. lactis INIA 639, a lacticin 481-producing strain, was used in the manufacture of Hispánico cheese together with L. lactis ssp. lactis INIA 437, a BNP strain, and Lb. helveticus LH 92, a culture with high aminopeptidase activity sensitive to lacticin 481 (Ávila et al., 2005b), with the aim of accelerating cheese ripening. The effect of milk inoculation with the BP culture on proteolysis, texture, and taste of Hispánico cheese are reported herein.

\section{MATERIALS AND METHODS}

\section{Lactic Cultures and Cheese Manufacture}

Lactococcus lactis ssp. lactis INIA 639, a lacticin 481producer from the culture collection of INIA (Madrid, Spain), was used as the BP strain. A BNP mutant of the lacticin 481-producer with acid production, proteolytic activity, and volatile compound profile in curd close to those of the parental strain could not be obtained. Therefore, L. lactis ssp. lactis INIA 437, a BNP strain with technological characteristics similar to those of the $\mathrm{BP}$, was selected for use in cheese-making experiments. Both strains were kept at $-80^{\circ} \mathrm{C}$ in de Man, Rogosa, and Sharpe broth (Biolife Italiana, Milano, Italy) with $15 \%$ glycerol, and grown twice in reconstituted skim milk at $25^{\circ} \mathrm{C}$ for $16 \mathrm{~h}$ before use in cheese manufacture. Lactobacillus helveticus LH 92 culture, kindly provided by Rhodia Iberia (Madrid, Spain), was kept at $-80^{\circ} \mathrm{C}$ and grown in reconstituted skim milk at $37^{\circ} \mathrm{C}$ for $10 \mathrm{~h}$ before use in cheese manufacture.

Hispánico cheese, a semihard Spanish variety, was manufactured from pasteurized cows' milk as described by Gómez et al. (1997). Experiments were carried out in duplicate on different days, at the Food Technology Department of INIA. Each experiment consisted of three 50-L vats; L. lactis ssp. lactis INIA 437 culture, with counts of $1.3 \times 10^{9} \mathrm{cfu} / \mathrm{mL}$, was added at $5 \mathrm{~mL} / \mathrm{L}$ to vat 1 and at $2.5 \mathrm{~mL} / \mathrm{L}$ to vat 2 , resulting in $6.5 \times 10^{6}$ and $3.3 \times 10^{6} \mathrm{cfu} / \mathrm{mL}$ in inoculated milk, respectively. Lactococcus lactis ssp. lactis INIA 639 culture, with counts of $8.4 \times 10^{8} \mathrm{cfu} / \mathrm{mL}$, was added at $2.5 \mathrm{~mL} / \mathrm{L}$ to vat 2 and at $5 \mathrm{~mL} / \mathrm{L}$ to vat 3 , resulting in $2.1 \times 10^{6}$ and $4.2 \times 10^{6} \mathrm{cfu} / \mathrm{mL}$ in inoculated milk, respectively. Lactobacillus helveticus LH 92 culture, with counts of $8.1 \times 10^{8} \mathrm{cfu} / \mathrm{mL}$, was added at $5 \mathrm{~mL} / \mathrm{L}$ to all vats, resulting in $4.1 \times 10^{6} \mathrm{cfu} / \mathrm{mL}$ in inoculated milk. Rennet (6 mL of Maxiren, 1:15,000 strength, Gist Brocades,
Delft, The Netherlands) was added to milk 30 min after lactic culture inoculation. The curds were cut $40 \mathrm{~min}$ later into 6- to 8-mm cubes and scalded at $37^{\circ} \mathrm{C}$ for 15 min. Whey was drained off and curds were distributed into cylindrical molds. Three cheeses, approximately 2 $\mathrm{kg}$ each, were obtained from each vat. Cheeses were pressed overnight at $20^{\circ} \mathrm{C}$ and $1.5 \mathrm{~kg} / \mathrm{cm}^{2}$ pressure, salted at $12^{\circ} \mathrm{C}$ for $24 \mathrm{~h}$ in brine $(160 \mathrm{~g}$ of $\mathrm{NaCl} / \mathrm{L})$, and ripened at $12^{\circ} \mathrm{C}$ and $85 \%$ relative humidity for $50 \mathrm{~d}$. Cheeses were coated on $d 7$ with 2 layers of polyvinyl acetate containing pimaricine.

To exclude an antagonistic effect of the BNP strain on $L b$. helveticus LH 92, cheeses were made from milk inoculated with $5 \mathrm{~mL} / \mathrm{L}$ Lb. helveticus $\mathrm{LH} 92$ and $5 \mathrm{~mL} /$ $\mathrm{L}$ of the BNP strain, and from milk inoculated only with $5 \mathrm{~mL} / \mathrm{L} \mathrm{Lb}$. helveticus $\mathrm{LH} 92$, following the above indicated manufacturing procedures, and ripened at $12^{\circ} \mathrm{C}$ and $85 \%$ relative humidity for $15 \mathrm{~d}$. Also, to ascertain the contribution of the BNP and BP strains to aminopeptidase levels and proteolysis values in cheese, cheeses were made from milk inoculated with $5 \mathrm{~mL} / \mathrm{L}$ of the BNP strain and $5 \mathrm{~mL} / \mathrm{L}$ of the $\mathrm{BP}$ strain, and from milk inoculated only with $5 \mathrm{~mL} / \mathrm{L}$ of the $\mathrm{BNP}$ strain, following the above indicated manufacturing procedures, and ripened at $12^{\circ} \mathrm{C}$ and $85 \%$ relative humidity for $15 \mathrm{~d}$.

\section{Microbiological Analysis}

Viable counts of lactococci were determined in duplicate on M17 agar (already containing $5.0 \mathrm{~g} / \mathrm{L}$ lactose, Biolife Italiana) using a spiral plater (Interscience, Saint-Nom-La-Bretèche, France), after aerobic incubation at $30^{\circ} \mathrm{C}$ for $48 \mathrm{~h}$. Bacteriocin-producing lactococci were determined on the surface of double-layer M17 agar plates, with the lower layer inoculated with $1 \mathrm{~mL} /$ $\mathrm{L}$ of a 16-h culture of $L$. lactis ssp. cremoris $\mathrm{HP}$ as the indicator microorganism; colonies forming a zone of growth inhibition in the lower layer were considered to be L. lactis ssp. lactis INIA 639. Lactobacillus helveticus counts were determined on de Man, Rogosa, and Sharpe agar plates incubated anaerobically for $48 \mathrm{~h}$ at $44^{\circ} \mathrm{C}$.

\section{Bacteriocin and Aminopeptidase Activities}

For the determination of bacteriocin activity, cheese samples held at $-40^{\circ} \mathrm{C}$ were thawed, and 5 -g samples were homogenized in a Stomacher 400 (Seward Laboratory, London, UK) with $10 \mathrm{~mL}$ of $0.02 \mathrm{~N} \mathrm{HCl}$ at $50^{\circ} \mathrm{C}$. Homogenates were centrifuged $(12,000 \times g, 20 \mathrm{~min}$, $4^{\circ} \mathrm{C}$ ), and the $\mathrm{pH}$ of fat-free supernatants was adjusted to $\mathrm{pH} 6$ with $1 \mathrm{~N} \mathrm{NaOH}$. A volume of $30 \mu \mathrm{L}$ of each supernatant was placed in triplicate into wells $(5 \mathrm{~mm}$ 
diameter) made in plates of M17 agar inoculated with $1 \mathrm{~mL} / \mathrm{L}$ of a 16 -h culture of L. lactis ssp. cremoris $\mathrm{HP}$ as the indicator microorganism. After incubation at $30^{\circ} \mathrm{C}$ for $48 \mathrm{~h}$, the diameter of the zone of growth inhibition was measured, and bacteriocin activity was expressed in millimeters.

Aminopeptidase activity released into the cheese was measured on duplicate samples with lysine $p$-nitroanilide (Lys-p-NA) as substrate (Garde et al., 1997). One activity unit corresponds to the activity of enzyme(s) producing one nanomole of $p$-nitroaniline per minute per gram of cheese.

\section{Chemical Determinations}

Cheese $\mathrm{pH}$ was measured in duplicate with a Crison penetration electrode (model 52-3,2; Crison Instruments, Barcelona, Spain) by means of a Crison GPL 22 pH meter (Ávila et al., 2005a). Dry matter was determined after drying to constant weight in vacuum oven at $100^{\circ} \mathrm{C}(\mathrm{AOAC}, 1990)$.

Residual caseins were determined by capillary electrophoresis, using a Beckman P/ACE System 2100 controlled by a System Gold Software data system (Beckman Instruments España, Madrid, Spain). A 5-g aliquot of grated cheese was homogenized with $25 \mathrm{~mL}$ of $2 \%$ trisodium citrate at $50^{\circ} \mathrm{C}$ using an Ultra-Turrax T8 homogenizer (IKA, Labortechnik, Staufen, Germany). Sample buffer was as previously described (Recio et al., 1997). Cheese and milk samples were prepared for capillary electrophoresis by mixing $100 \mu \mathrm{L}$ of homogenate with $900 \mu \mathrm{L}$ of sample buffer. Samples were kept for $60 \mathrm{~min}$ at room temperature, filtered through a mixture of cellulose esters $0.45-\mu \mathrm{m}$ filter (Teknokroma, Sant Cugat del Vallès, Spain), and injected in duplicate at the anode using $\mathrm{N}_{2}$ at $0.035 \mathrm{~kg} / \mathrm{cm}^{2}$ for $15 \mathrm{~s}$. Separation was performed in a hydrophilic coated fused-silica capillary column CElect P150 (Supelco, Bellefonte, PA), $37 \mathrm{~cm}$ long (30-cm effective length), with a final applied voltage of $13 \mathrm{kV}$. Detection of peaks was at $214 \mathrm{~nm}$. Residual caseins in cheese were expressed as percentage of the total amount of the respective casein initially present in milk, taking into account total weights of milk and cheese sampled (Picón et al., 1994).

Cheese proteolysis was determined on duplicate samples by the $o$-phthaldialdehyde (OPA) test, based on the reaction of released $\alpha$-amino groups with this compound and with $\beta$-mercaptoethanol to form an adduct that absorbs strongly at $340 \mathrm{~nm}$ (Church et al., 1983).

Hydrophilic and hydrophobic peptides in the watersoluble fraction of cheese were determined on duplicate samples by reverse phase-HPLC using a Beckman System Gold chromatograph (Beckman Instruments España) equipped with a diode array detector module 168 , with detection wavelength at $214 \mathrm{~nm}$, as previously described (Lau et al., 1991; Gómez et al., 1997). Peaks with retention times from 8.5 to 14.6 min were considered to correspond to hydrophilic peptides, and those with retention times from 14.6 to $20.5 \mathrm{~min}$ to hydrophobic peptides. Results were expressed in arbitrary units of chromatogram area per milligram of cheese DM.

Free amino acids were extracted from duplicate samples of cheese (Krause et al., 1995) and individual amino acids determined by reverse phase-HPLC using a Beckman System Gold chromatograph after derivatization with 6-aminoquinolyl-N-hydroxysuccinimidyl carbamate (Cohen and Michaud, 1993). Results were expressed as milligrams per gram of cheese DM.

\section{Textural Determinations}

Six cylindrical samples $(17 \mathrm{~mm}$ height $\times 17 \mathrm{~mm}$ diameter) from each cheese were compressed to $75 \%$ of their original height after being held for $2 \mathrm{~h}$ at 20 to $22^{\circ} \mathrm{C}$, using an Instron Compression Tester 4301 (Instron, High Wycombe, UK) with a crosshead speed of $50 \mathrm{~mm} /$ min and 1-kN load cell. Fracturability (expressed in newtons), hardness after $75 \%$ compression (expressed in joules), and elasticity (expressed in newtons $/ \mathrm{mm}^{2}$ ) were calculated as previously described (Gaya et al., 1990) from the compression curves obtained.

\section{Sensory Evaluation}

Twelve trained panelists scored the cheeses at 25 and $50 \mathrm{~d}$ of ripening for quality (overall acceptance) and intensity (overall intensity) of taste on a 10-point scale, using a horizontal line anchored in the middle and at both ends. Taste was defined as the sensation felt by the taste buds. Cheese samples were held for $3 \mathrm{~h}$ at 20 to $22^{\circ} \mathrm{C}$ before sensorial evaluation. After removing the rind, cheeses were cut into wedges and wedges cut into representative triangular slices (15 to $20 \mathrm{~g}$ each). Three cheeses per session, one from each of the vats manufactured on the same day, coded with random 3-digit numbers, were presented to panelists in randomized order. Bread and water were used as rinsing agents between cheeses. A descriptive sensory test was developed for Hispánico cheese and panelists were trained following the guidelines for the taste evaluation of hard and semihard cheeses recommended by Bérodier et al. (1997). Panelists were asked to assign a score on a 0 to 6 scale, using a horizontal line anchored in the middle and at both ends, to the intensity of the following taste attributes: sour, bitter, sweet, salty, and umami.

\section{Statistical Analyses}

Statistics were performed by means of SPSS Win program (version 8.0, SPSS Inc., Chicago, IL). The AN- 
Table 1. Lactic acid bacteria (LAB) counts in Hispánico cheese manufactured with lacticin 481-producing (BP) Lactococcus lactis ssp. lactis INIA 639, bacteriocin-nonproducing (BNP) L. lactis ssp. lactis INIA 437, and a Lactobacillus helveticus culture (LH) ${ }^{1}$

\begin{tabular}{llcc}
\hline & \multicolumn{3}{c}{ Experimental cheeses $^{2}$} \\
\cline { 2 - 4 } Age & \multicolumn{3}{c}{ BNP + BP } \\
& BNP + LH & LH & BP + LH \\
\hline $\begin{array}{c}\text { Mesophilic LAB } \\
\text { (log cfu/g) }\end{array}$ & & \\
6 h & $8.99 \pm 0.07^{\mathrm{a}}$ & $8.93 \pm 0.04^{\mathrm{a}}$ & $8.90 \pm 0.04^{\mathrm{a}}$ \\
$1 \mathrm{~d}$ & $9.38 \pm 0.01^{\mathrm{c}}$ & $9.28 \pm 0.02^{\mathrm{b}}$ & $9.15 \pm 0.07^{\mathrm{a}}$ \\
$7 \mathrm{~d}$ & $9.35 \pm 0.16^{\mathrm{b}}$ & $9.21 \pm 0.07^{\mathrm{a}}$ & $9.13 \pm 0.05^{\mathrm{a}}$ \\
$15 \mathrm{~d}$ & $9.16 \pm 0.01^{\mathrm{b}}$ & $9.05 \pm 0.02^{\mathrm{a}}$ & $9.04 \pm 0.11^{\mathrm{a}}$ \\
$25 \mathrm{~d}$ & $9.38 \pm 0.03^{\mathrm{c}}$ & $8.99 \pm 0.04^{\mathrm{b}}$ & $8.64 \pm 0.30^{\mathrm{a}}$ \\
$50 \mathrm{~d}$ & $9.32 \pm 0.01^{\mathrm{c}}$ & $8.65 \pm 0.04^{\mathrm{b}}$ & $7.44 \pm 0.04^{\mathrm{a}}$ \\
Thermophilic LAB & & & \\
(log cfu/g) & & & \\
$6 \mathrm{~h}$ & $7.39 \pm 0.01^{\mathrm{c}}$ & $6.46 \pm 0.10^{\mathrm{b}}$ & $5.12 \pm 0.21^{\mathrm{a}}$ \\
$1 \mathrm{~d}$ & $7.62 \pm 0.06^{\mathrm{c}}$ & $4.75 \pm 0.46^{\mathrm{a}}$ & $5.35 \pm 0.04^{\mathrm{b}}$ \\
$7 \mathrm{~d}$ & $8.20 \pm 0.19^{\mathrm{c}}$ & $6.27 \pm 0.26^{\mathrm{b}}$ & $5.78 \pm 0.25^{\mathrm{a}}$ \\
$15 \mathrm{~d}$ & $7.67 \pm 0.07^{\mathrm{c}}$ & $5.55 \pm 0.21^{\mathrm{a}}$ & $5.91 \pm 0.09^{\mathrm{b}}$ \\
$25 \mathrm{~d}$ & $7.20 \pm 0.09^{\mathrm{c}}$ & $5.51 \pm 0.25^{\mathrm{a}}$ & $5.89 \pm 0.02^{\mathrm{b}}$ \\
$50 \mathrm{~d}$ & $6.85 \pm 0.13^{\mathrm{c}}$ & $4.77 \pm 0.36^{\mathrm{a}}$ & $5.53 \pm 0.28^{\mathrm{b}}$ \\
\hline
\end{tabular}

${ }^{\mathrm{a}-\mathrm{c}}$ Means in the same row with the same superscript do not differ $(P<0.05)$.

${ }^{1}$ Mean $\pm \mathrm{SE}(\mathrm{n}=4)$ of duplicate determinations on 2 cheese-making experiments.

${ }^{2}$ Cheeses: $\mathrm{BNP}+\mathrm{LH}=5 \mathrm{~mL} / \mathrm{L}$ of bacteriocin-nonproducing $L$. lactis ssp. lactis INIA 437, and $5 \mathrm{~mL} / \mathrm{L}$ of a Lactobacillus helveticus culture; $\mathrm{BNP}+\mathrm{BP}+\mathrm{LH}=2.5 \mathrm{~mL} / \mathrm{L}$ of bacteriocin-nonproducing $L$. lactis $\mathrm{ssp}$. lactis INIA 437, $2.5 \mathrm{~mL} / \mathrm{L}$ of lacticin 481-producing Lactococcus lactis ssp. lactis INIA 639 , and $5 \mathrm{~mL} / \mathrm{L}$ of a Lactobacillus helveticus culture; $\mathrm{BP}+\mathrm{LH}=5 \mathrm{~mL} / \mathrm{L}$ of a lacticin 481-producing Lactococcus lactis ssp. lactis INIA 639 , and $5 \mathrm{~mL} / \mathrm{L}$ of a Lactobacillus helveticus culture.

OVA was carried out with type of mesophilic starter, cheese age, and cheese-making experiment as main effects. Comparison of means was performed using Tukey's test. Principal component analysis with Varimax rotation was carried out on $\mathrm{pH}$, proteolysis parameters, and taste attributes.

\section{RESULTS AND DISCUSSION}

\section{$L A B$ and Cheese $p H$}

Mesophilic LAB in BNP cheese corresponded to $L$. lactis ssp. lactis INIA 437, in BNP + BP cheese to $L$. lactis ssp. lactis INIA 437 plus L. lactis ssp. lactis INIA 639, and in BP cheese to L. lactis ssp. lactis INIA 639. The highest mesophilic LAB counts were found in BNP cheese throughout the ripening period (Table 1), with differences in counts with respect to the other cheeses increasing with age. The BP-LAB accounted for $36 \%$ of the mesophilic LAB in BNP + BP cheese on $d 1$, but for only $1 \%$ on d 50 (Table 2). Decreases in counts of BP$\mathrm{LAB}$ of 2.05 and $1.74 \mathrm{log}$ units were recorded from $\mathrm{d} 1$ to $\mathrm{d} 50$ in $\mathrm{BNP}+\mathrm{BP}$ and in $\mathrm{BP}$ cheeses, respectively. The higher reduction of BP-LAB counts in BNP + BP cheese than in $\mathrm{BP}$ cheese could be due to the fact that
Table 2. Bacteriocin-producer counts and bacteriocin activity in Hispánico cheese manufactured with lacticin 481-producing (BP) Lactococcus lactis ssp. lactis INIA 639, bacteriocin-nonproducing (BNP) $L$. lactis ssp. lactis INIA 437, and a Lactobacillus helveticus culture $(\mathrm{LH})^{1}$

\begin{tabular}{|c|c|c|c|}
\hline \multirow[b]{2}{*}{ Age } & \multicolumn{3}{|c|}{ Experimental cheeses ${ }^{2}$} \\
\hline & $\begin{array}{l}\mathrm{BNP} \\
+\mathrm{LH}\end{array}$ & $\begin{array}{l}\mathrm{BNP}+\mathrm{BP} \\
+\mathrm{LH}\end{array}$ & $\mathrm{BP}+\mathrm{LH}$ \\
\hline \multicolumn{4}{|c|}{$\begin{array}{l}\text { Bacteriocin-producer count } \\
(\log \mathrm{cfu} / \mathrm{g})\end{array}$} \\
\hline $6 \mathrm{~h}$ & $\mathrm{ND}^{\mathrm{a}}$ & $8.45 \pm 0.06^{b}$ & $8.75 \pm 0.05^{c}$ \\
\hline $1 \mathrm{~d}$ & $\mathrm{ND}^{\mathrm{a}}$ & $8.83 \pm 0.06^{b}$ & $9.17 \pm 0.10^{\mathrm{c}}$ \\
\hline $7 \mathrm{~d}$ & $\mathrm{ND}^{\mathrm{a}}$ & $8.79 \pm 0.05^{\mathrm{b}}$ & $9.12 \pm 0.08^{c}$ \\
\hline $15 \mathrm{~d}$ & $\mathrm{ND}^{\mathrm{a}}$ & $8.67 \pm 0.04^{b}$ & $9.06 \pm 0.12^{\mathrm{c}}$ \\
\hline $25 \mathrm{~d}$ & $\mathrm{ND}^{\mathrm{a}}$ & $8.43 \pm 0.27^{b}$ & $8.70 \pm 0.24^{\mathrm{c}}$ \\
\hline $50 \mathrm{~d}$ & $\mathrm{ND}^{\mathrm{a}}$ & $6.78 \pm 0.17^{b}$ & $7.43 \pm 0.06^{\mathrm{c}}$ \\
\hline \multicolumn{4}{|c|}{$\begin{array}{l}\text { Bacteriocin } \\
\text { (mm inhibition) }\end{array}$} \\
\hline $6 \mathrm{~h}$ & $\mathrm{ND}^{\mathrm{a}}$ & $\mathrm{ND}^{\mathrm{a}}$ & $9.3 \pm 0.3^{b}$ \\
\hline $1 \mathrm{~d}$ & $\mathrm{ND}^{\mathrm{a}}$ & $8.0 \pm 0.3^{b}$ & $10.8 \pm 0.3^{\mathrm{c}}$ \\
\hline $7 \mathrm{~d}$ & $\mathrm{ND}^{\mathrm{a}}$ & $9.3 \pm 0.3^{\mathrm{b}}$ & $11.8 \pm 0.1^{\mathrm{c}}$ \\
\hline $15 \mathrm{~d}$ & $\mathrm{ND}^{\mathrm{a}}$ & $9.8 \pm 0.1^{\mathrm{b}}$ & $12.3 \pm 0.1^{\mathrm{c}}$ \\
\hline $25 \mathrm{~d}$ & $\mathrm{ND}^{\mathrm{a}}$ & $\mathrm{ND}^{\mathrm{a}}$ & $10.0 \pm 0.0^{\mathrm{b}}$ \\
\hline $50 \mathrm{~d}$ & $\mathrm{ND}^{\mathrm{a}}$ & $\mathrm{ND}^{\mathrm{a}}$ & $10.3 \pm 0.4^{\mathrm{b}}$ \\
\hline
\end{tabular}

${ }^{\mathrm{a}-\mathrm{c}}$ Means in the same row with the same superscript do not differ $(P<0.05)$.

${ }^{1}$ Mean $\pm \mathrm{SE}(\mathrm{n}=4)$ of duplicate determinations on 2 cheese-making experiments; $\mathrm{ND}=$ not detected.

${ }^{2}$ Cheeses: $\mathrm{BNP}+\mathrm{LH}=5 \mathrm{~mL} / \mathrm{L}$ of bacteriocin-nonproducing $L$. lactis ssp. lactis INIA 437, and $5 \mathrm{~mL} / \mathrm{L}$ of a Lactobacillus helveticus culture; $\mathrm{BNP}+\mathrm{BP}+\mathrm{LH}=2.5 \mathrm{~mL} / \mathrm{L}$ of bacteriocin-nonproducing $L$. lactis ssp. lactis INIA 437, $2.5 \mathrm{~mL} / \mathrm{L}$ of lacticin 481-producing Lactococcus lactis ssp. lactis INIA 639 , and $5 \mathrm{~mL} / \mathrm{L}$ of a Lactobacillus helveticus culture; $\mathrm{BP}+\mathrm{LH}=5 \mathrm{~mL} / \mathrm{L}$ of a lacticin 481-producing Lactococcus lactis ssp. lactis INIA 639 , and $5 \mathrm{~mL} / \mathrm{L}$ of a Lactobacillus helveticus culture.

in the former cheese, the BP strain has to compete for nutrients with the BNP strain. On the other hand, BNP-LAB only decreased by 0.06 log units in BNP cheese and by 0.45 log units in BNP + BP cheese from d 1 to d 50 .

The increase in thermophilic LAB counts from inoculated milk to 6-h BNP cheese, considerably lower than that of mesophilic LAB, can be mostly ascribed to bacterial concentration in the curds. Log counts of thermophilic LAB in cheese made from milk inoculated with Lb. helveticus LH 92 and the BNP strain did not differ significantly from those in cheese made from milk inoculated only with $L b$. helveticus LH 92 during the first $15 \mathrm{~d}$ of ripening (data not shown), excluding any antagonistic affect of the BNP strain on Lb. helveticus LH 92. On the other hand, death of thermophilic LAB occurred in cheeses made with BP culture during the first hours, with counts 0.93 and $2.27 \log$ units lower in BNP + BP and BP cheeses, respectively, than in BNP cheese after $6 \mathrm{~h}$ (Table 1). In BNP + BP cheese, death of thermophilic LAB still continued from 6 to $24 \mathrm{~h}$. Recovery and growth of thermophilic LAB was observed in BP cheese from $6 \mathrm{~h}$ and in BNP + BP cheese from $24 \mathrm{~h}$ (Table 1). Lower 
Table 3. Values of $\mathrm{pH}$ and DM in Hispánico cheese manufactured with lacticin 481-producing (BP) Lactococcus lactis ssp. lactis INIA 639, bacteriocin-nonproducing (BNP) L. lactis ssp. lactis INIA 437, and a Lactobacillus helveticus culture (LH) ${ }^{1}$

\begin{tabular}{lccc}
\hline & \multicolumn{3}{c}{ Experimental cheeses $^{2}$} \\
\cline { 2 - 4 } Age & BNP $+\mathrm{LH}$ & $\mathrm{BNP}+\mathrm{BP}+\mathrm{LH}$ & $\mathrm{BP}+\mathrm{LH}$ \\
\hline Cheese pH & & & \\
$6 \mathrm{~h}$ & $5.15 \pm 0.06^{\mathrm{a}}$ & $5.18 \pm 0.05^{\mathrm{a}}$ & $5.13 \pm 0.07^{\mathrm{a}}$ \\
$1 \mathrm{~d}$ & $4.97 \pm 0.04^{\mathrm{a}}$ & $4.91 \pm 0.03^{\mathrm{a}}$ & $4.97 \pm 0.02^{\mathrm{a}}$ \\
$7 \mathrm{~d}$ & $4.97 \pm 0.08^{\mathrm{a}}$ & $4.91 \pm 0.06^{\mathrm{a}}$ & $4.97 \pm 0.04^{\mathrm{a}}$ \\
$15 \mathrm{~d}$ & $4.88 \pm 0.05^{\mathrm{a}}$ & $4.97 \pm 0.11^{\mathrm{b}}$ & $4.99 \pm 0.06^{\mathrm{b}}$ \\
$25 \mathrm{~d}$ & $4.87 \pm 0.04^{\mathrm{a}}$ & $4.89 \pm 0.03^{\mathrm{a}}$ & $4.90 \pm 0.06^{\mathrm{a}}$ \\
$50 \mathrm{~d}$ & $4.81 \pm 0.05^{\mathrm{a}}$ & $4.89 \pm 0.02^{\mathrm{a}}$ & $4.86 \pm 0.01^{\mathrm{a}}$ \\
DM $(\%)$ & & & \\
$25 \mathrm{~d}$ & $55.77 \pm 0.54^{\mathrm{a}}$ & $54.94 \pm 0.59^{\mathrm{a}}$ & $56.20 \pm 0.31^{\mathrm{a}}$ \\
$50 \mathrm{~d}$ & $58.85 \pm 0.59^{\mathrm{a}}$ & $59.19 \pm 0.27^{\mathrm{a}}$ & $58.72 \pm 0.64^{\mathrm{a}}$ \\
\hline
\end{tabular}

${ }^{\mathrm{a}, \mathrm{b}}$ Means in the same row with the same superscript do not differ $(P<0.05)$.

${ }^{1}$ Mean \pm SE $(n=4)$ of duplicate determinations on 2 cheese-making experiments.

${ }^{2}$ Cheeses: $\mathrm{BNP}+\mathrm{LH}=5 \mathrm{~mL} / \mathrm{L}$ of bacteriocin-nonproducing $L$. lactis ssp. lactis INIA 437, and $5 \mathrm{~mL} / \mathrm{L}$ of a Lactobacillus helveticus culture; $\mathrm{BNP}+\mathrm{BP}+\mathrm{LH}=2.5 \mathrm{~mL} / \mathrm{L}$ of bacteriocin-nonproducing L. lactis $\mathrm{ssp}$. lactis INIA 437, $2.5 \mathrm{~mL} / \mathrm{L}$ of lacticin 481-producing Lactococcus lactis ssp. lactis INIA 639, and $5 \mathrm{~mL} / \mathrm{L}$ of a Lactobacillus helveticus culture; $\mathrm{BP}+\mathrm{LH}=5 \mathrm{~mL} / \mathrm{L}$ of a lacticin 481-producing Lactococcus lactis ssp. lactis INIA 639 , and $5 \mathrm{~mL} / \mathrm{L}$ of a Lactobacillus helveticus culture.

LAB counts had been reported in previous works when a BP strain was added in cheese making (Garde et al., 2002a; Benech et al., 2003; Sallami et al., 2004a; Ávila et al., 2005a).

No significant differences in cheese $\mathrm{pH}$ during ripening were found, except on $\mathrm{d} 15$, when the $\mathrm{pH}$ was higher in cheeses made with BP than in BNP cheeses (Table 3 ). Retarded acid production in cheese made from milk inoculated with a BP adjunct has been reported by some authors (Garde et al., 1997; Morgan et al., 1997). There were no significant differences in DM between cheeses throughout the ripening period (Table 3).

\section{Bacteriocin Activity and Release of Intracellular Enzymes}

Bacteriocin activity in cheeses made with BP increased until d 15, and decreased afterwards (Table 2). Bacteriocin activity was higher in BP cheese than in $\mathrm{BNP}+\mathrm{BP}$ cheese, in agreement with the higher counts of the $\mathrm{BP}$ in the former cheese (Table 2).

Cell-free aminopeptidase activity increased significantly $(P<0.001)$ as cheese aged (Table 4$)$. Aminopeptidase levels remained below 0.5 activity units during the first $15 \mathrm{~d}$ of ripening in cheese from milk inoculated only with the BNP strain, and below 2.5 activity units in cheese from milk inoculated only with BNP and BP strains (data not shown), values considerably lower than those found in cheeses from milk inoculated also
Table 4. Cell-free aminopeptidase activity (nmol of lysine $p$-nitroanilide/min $\times g$ ) in Hispánico cheese manufactured with lacticin 481producing (BP) Lactococcus lactis ssp. lactis INIA 639, bacteriocinnonproducing (BNP) L. lactis ssp. lactis INIA 437, and a Lactobacillus helveticus culture $(\mathrm{LH})^{1}$

\begin{tabular}{lccl}
\hline & \multicolumn{3}{c}{ Experimental cheeses $^{2}$} \\
\cline { 2 - 4 } Age & BNP $+\mathrm{LH}$ & $\mathrm{BNP}+\mathrm{BP}+\mathrm{LH}$ & $\mathrm{BP}+\mathrm{LH}$ \\
\hline $6 \mathrm{~h}$ & $9.53 \pm 1.30^{\mathrm{a}}$ & $12.06 \pm 0.35^{\mathrm{b}}$ & $11.53 \pm 0.50^{\mathrm{b}}$ \\
$1 \mathrm{~d}$ & $16.08 \pm 3.15^{\mathrm{a}}$ & $18.30 \pm 1.84^{\mathrm{b}}$ & $14.79 \pm 1.54^{\mathrm{a}}$ \\
$7 \mathrm{~d}$ & $29.47 \pm 6.26^{\mathrm{a}}$ & $41.15 \pm 2.38^{\mathrm{b}}$ & $32.38 \pm 2.16^{\mathrm{a}}$ \\
$15 \mathrm{~d}$ & $32.94 \pm 4.78^{\mathrm{b}}$ & $57.53 \pm 1.05^{\mathrm{c}}$ & $26.96 \pm 0.86^{\mathrm{a}}$ \\
$25 \mathrm{~d}$ & $37.56 \pm 7.82^{\mathrm{b}}$ & $53.67 \pm 9.41^{\mathrm{c}}$ & $27.58 \pm 2.66^{\mathrm{a}}$ \\
$50 \mathrm{~d}$ & $39.87 \pm 6.93^{\mathrm{a}}$ & $64.83 \pm 7.01^{\mathrm{b}}$ & $34.79 \pm 0.85^{\mathrm{a}}$ \\
\hline
\end{tabular}

${ }^{\mathrm{a}-\mathrm{c}}$ Means in the same row with the same superscript do not differ $(P<0.05)$.

${ }^{1}$ Mean $\pm \mathrm{SE}(\mathrm{n}=4)$ of duplicate determinations on 2 cheese-making experiments.

${ }^{2}$ Cheeses: $\mathrm{BNP}+\mathrm{LH}=5 \mathrm{~mL} / \mathrm{L}$ of bacteriocin-nonproducing $L$. lactis ssp. lactis INIA 437 , and $5 \mathrm{~mL} / \mathrm{L}$ of a Lactobacillus helveticus culture; $\mathrm{BNP}+\mathrm{BP}+\mathrm{LH}=2.5 \mathrm{~mL} / \mathrm{L}$ of bacteriocin-nonproducing $L$. lactis $\mathrm{ssp}$. lactis INIA 437, $2.5 \mathrm{~mL} / \mathrm{L}$ of lacticin 481-producing Lactococcus lactis ssp. lactis INIA 639 , and $5 \mathrm{~mL} / \mathrm{L}$ of a Lactobacillus helveticus culture; $\mathrm{BP}+\mathrm{LH}=5 \mathrm{~mL} / \mathrm{L}$ of a lacticin 481-producing Lactococcus lactis $\mathrm{ssp}$. lactis INIA 639 , and $5 \mathrm{~mL} / \mathrm{L}$ of a Lactobacillus helveticus culture.

with $L b$. helveticus LH 92 (Table 4). Cheese made with $\mathrm{BNP}+\mathrm{BP}$ showed the highest cell-free aminopeptidase activity values, 1.4- to 1.8 -fold higher than those in BNP cheese from $d 7$ onwards. The increase in cell-free aminopeptidase activity due to bacteriocin-mediated lysis of LAB was in agreement with previous reports (Garde et al., 1997; Morgan et al., 1997; MartínezCuesta et al., 2001; Garde et al., 2002a; Ávila et al., 2005a). However, BP cheese showed cell-free aminopeptidase activity values similar to or lower than those of BNP cheese. The considerable bacteriocin production during the first $6 \mathrm{~h}$ in BP cheese (Table 2) inhibited growth of $L b$. helveticus, which, after $6 \mathrm{~h}$, reached counts 1.34 log units lower in BP cheese than in BNP + BP cheese (Table 1), which undoubtedly affected aminopeptidase activity value (Table 4$)$. The retarded bacteriocin production in $\mathrm{BNP}+\mathrm{BP}$ cheese with respect to $\mathrm{BP}$ cheese delayed $L b$. helveticus inhibition and death. Counts of Lb. helveticus decreased by $1.71 \mathrm{log}$ units in BNP + BP cheese from 6 to $24 \mathrm{~h}$ (Table 1), and the concomitant cell lysis resulted in high aminopeptidase activity values throughout ripening (Table 4). From d 1 to d 7, Lb. helveticus cells recovered in BNP + BP cheese (Table 1). Simultaneously, intracellular aminopeptidases were released, as shown by the 2.2fold increase in the activity value of this cheese (Table 4). O'Sullivan et al. (2002) observed that some cells in a lactococcal culture exposed to lacticin 481 suffered gradual death and lysis/permeabilization, whereas other cells continued to grow. These authors suggested that the different growth phase, the physiological sta- 
Table 5. Overall proteolysis $\left(\mathrm{A}_{340 \mathrm{~nm}}\right)$ in Hispánico cheese manufactured with lacticin 481-producing (BP) Lactococcus lactis ssp. lactis INIA 639, bacteriocin-nonproducing (BNP) L. lactis ssp. lactis INIA 437, and a Lactobacillus helveticus culture $(\mathrm{LH})^{1}$

\begin{tabular}{llll}
\hline & \multicolumn{3}{c}{ Experimental cheeses $^{2}$} \\
\cline { 2 - 4 } Age & $\mathrm{BNP}+\mathrm{LH}$ & $\mathrm{BNP}+\mathrm{BP}+\mathrm{LH}$ & $\mathrm{BP}+\mathrm{LH}$ \\
\hline $1 \mathrm{~d}$ & $0.163 \pm 0.005^{\mathrm{b}}$ & $0.158 \pm 0.004^{\mathrm{a}}$ & $0.167 \pm 0.012^{\mathrm{b}}$ \\
$7 \mathrm{~d}$ & $0.490 \pm 0.105^{\mathrm{a}}$ & $0.767 \pm 0.120^{\mathrm{c}}$ & $0.713 \pm 0.089^{\mathrm{b}}$ \\
$15 \mathrm{~d}$ & $0.665 \pm 0.088^{\mathrm{a}}$ & $1.246 \pm 0.087^{\mathrm{c}}$ & $1.127 \pm 0.051^{\mathrm{b}}$ \\
$25 \mathrm{~d}$ & $0.935 \pm 0.088^{\mathrm{a}}$ & $1.900 \pm 0.063^{\mathrm{c}}$ & $1.661 \pm 0.060^{\mathrm{b}}$ \\
$50 \mathrm{~d}$ & $2.188 \pm 0.317^{\mathrm{a}}$ & $3.604 \pm 0.414^{\mathrm{c}}$ & $3.153 \pm 0.293^{\mathrm{b}}$ \\
\hline
\end{tabular}

${ }^{\mathrm{a}-\mathrm{c}}$ Means in the same row with the same superscript do not differ $(P<0.05)$.

${ }^{1}$ Mean $\pm \mathrm{SE}(\mathrm{n}=4)$ of duplicate determinations on 2 cheese-making experiments.

${ }^{2}$ Cheeses: $\mathrm{BNP}+\mathrm{LH}=5 \mathrm{~mL} / \mathrm{L}$ of bacteriocin-nonproducing $L$. lactis ssp. lactis INIA 437, and $5 \mathrm{~mL} / \mathrm{L}$ of a Lactobacillus helveticus culture; $\mathrm{BNP}+\mathrm{BP}+\mathrm{LH}=2.5 \mathrm{~mL} / \mathrm{L}$ of bacteriocin-nonproducing $L$. lactis $\mathrm{ssp}$. lactis INIA 437, $2.5 \mathrm{~mL} / \mathrm{L}$ of lacticin 481-producing Lactococcus lactis ssp. lactis INIA 639 , and $5 \mathrm{~mL} / \mathrm{L}$ of a Lactobacillus helveticus culture; $\mathrm{BP}+\mathrm{LH}=5 \mathrm{~mL} / \mathrm{L}$ of a lacticin 481-producing Lactococcus lactis ssp. lactis INIA 639 , and $5 \mathrm{~mL} / \mathrm{L}$ of a Lactobacillus helveticus culture.

tus of individual cells, or a low ratio of lacticin 481 molecules to cells could have been involved in the different sensitivity of lactococcal cells to the bacteriocin. In the present work, the particular mode of action of lacticin 481 would explain growth of $L b$. helveticus from $\mathrm{d} 1$ to $\mathrm{d} 7$ in BNP + BP cheese with simultaneous release of intracellular aminopeptidases, in agreement with the high aminopeptidase activity values obtained for mixed cultures of $L b$. helveticus and lacticin 481-producing strains in milk (Ávila et al., 2005b).

\section{Proteolysis}

Cheese proteolysis, as determined by the OPA test, which detects released $\alpha$-amino groups, increased significantly $(P<0.001)$ with cheese age (Table 5$)$. Proteolysis values remained below 0.30 during the first $15 \mathrm{~d}$ of ripening in cheese from milk inoculated only with the BNP strain, and below 0.40 in cheese from milk inoculated only with BNP and BP strains (data not shown), levels considerably lower than those found in cheeses from milk inoculated also with $L b$. helveticus LH 92 (Table 5). The BNP + BP cheese showed the highest proteolysis values throughout ripening, followed by BP cheese. After $25 \mathrm{~d}$ of ripening, proteolysis in BNP + BP cheese was 2.0-fold higher than that in BNP cheese. Enhancement of cheese proteolysis was associated with lower levels of viable thermophilic LAB (Table 1) and with a higher aminopeptidase activity (Table 4). These results confirm that early death of LAB cells caused by a bacteriocin increases the release of peptidases and therefore cheese proteolysis (Garde et al., 1997; Martínez-Cuesta et al., 2001; Garde et al.,
Table 6. Residual caseins (\%) in Hispánico cheese manufactured with lacticin 481-producing (BP) Lactococcus lactis ssp. lactis INIA 639, bacteriocin-nonproducing (BNP) L. lactis ssp. lactis INIA 437, and a Lactobacillus helveticus culture $(\mathrm{LH})^{1}$

\begin{tabular}{lccr}
\hline & \multicolumn{3}{c}{ Experimental cheeses $^{2}$} \\
\cline { 2 - 4 } Age & $\mathrm{BNP}+\mathrm{LH}$ & $\mathrm{BNP}+\mathrm{BP}+\mathrm{LH}$ & $\mathrm{BP}+\mathrm{LH}$ \\
\hline$\alpha_{\mathrm{S}}$-Casein & & & \\
$1 \mathrm{~d}$ & $58.7 \pm 2.2^{\mathrm{a}}$ & $57.6 \pm 3.2^{\mathrm{a}}$ & $63.8 \pm 1.8^{\mathrm{a}}$ \\
$25 \mathrm{~d}$ & $22.1 \pm 3.9^{\mathrm{b}}$ & $15.6 \pm 0.4^{\mathrm{a}}$ & $16.3 \pm 0.4^{\mathrm{a}}$ \\
$50 \mathrm{~d}$ & $14.7 \pm 3.5^{\mathrm{b}}$ & $9.7 \pm 0.7^{\mathrm{a}}$ & $8.8 \pm 0.3^{\mathrm{a}}$ \\
$\beta$-Casein & & & \\
$1 \mathrm{~d}$ & $83.2 \pm 2.8^{\mathrm{a}}$ & $79.2 \pm 4.3^{\mathrm{a}}$ & $85.2 \pm 3.8^{\mathrm{a}}$ \\
$25 \mathrm{~d}$ & $70.7 \pm 0.7^{\mathrm{b}}$ & $63.0 \pm 2.7^{\mathrm{a}}$ & $71.0 \pm 4.2^{\mathrm{b}}$ \\
$50 \mathrm{~d}$ & $62.2 \pm 2.4^{\mathrm{a}}$ & $58.5 \pm 5.1^{\mathrm{a}}$ & $53.0 \pm 2.8^{\mathrm{a}}$ \\
\hline
\end{tabular}

${ }^{\mathrm{a}, \mathrm{b}}$ Means in the same row with the same superscript do not differ $(P<0.05)$.

${ }^{1}$ Mean $\pm \operatorname{SE}(n=4)$ of duplicate determinations on 2 cheese-making experiments.

${ }^{2}$ Cheeses: $\mathrm{BNP}+\mathrm{LH}=5 \mathrm{~mL} / \mathrm{L}$ of bacteriocin-nonproducing $L$. lactis ssp. lactis INIA 437, and $5 \mathrm{~mL} / \mathrm{L}$ of a Lactobacillus helveticus culture; $\mathrm{BNP}+\mathrm{BP}+\mathrm{LH}=2.5 \mathrm{~mL} / \mathrm{L}$ of bacteriocin-nonproducing $L$. lactis $\mathrm{ssp}$. lactis INIA $437,2.5 \mathrm{~mL} / \mathrm{L}$ of lacticin 481-producing Lactococcus lactis ssp. lactis INIA 639 , and $5 \mathrm{~mL} / \mathrm{L}$ of a Lactobacillus helveticus culture; $\mathrm{BP}+\mathrm{LH}=5 \mathrm{~mL} / \mathrm{L}$ of a lacticin 481-producing Lactococcus lactis ssp. lactis INIA 639, and $5 \mathrm{~mL} / \mathrm{L}$ of a Lactobacillus helveticus culture.

2002a; Ávila et al., 2005a). A higher release of free $\mathrm{NH}_{2}$ groups in cheese made with an autolytic $L b$. helveticus strain than in cheese made with a nonautolytic $L b$. helveticus strain has also been reported (Valence et al., 2000).

Residual $\alpha_{S^{-}}$casein declined considerably during ripening in all cheeses (Table 6), from 58 to $64 \%$ on $\mathrm{d} 1$ to 9 to $15 \%$ on d 50 , whereas $\beta$-casein was scarcely degraded, with 80 to $85 \%$ intact casein on $d 1$ and 53 to $62 \%$ on $d$ 50. Levels of $\alpha_{\mathrm{S}}$-casein, but not $\beta$-casein, were significantly $(P<0.05)$ lower in BP cheeses than BNP cheeses from d 25 onwards. The lower $\mathrm{pH}$ value of the latter cheese from d 15 onwards might have retarded the activity of caseinolytic enzymes.

The highest levels of hydrophilic and hydrophobic peptides were found in BNP cheese, followed by BP cheese (Table 7). After $50 \mathrm{~d}$, levels of hydrophilic and hydrophobic peptides in BNP cheese were 2.1- and 1.3fold higher than in BNP + BP cheese, respectively. The hydrophobic:hydrophilic ratio declined in all cheeses during ripening, with significantly lower values in BNP $+\mathrm{BP}$ cheese. Because hydrophobic peptides and the hydrophobic:hydrophilic ratio are associated with cheese bitterness (Lau et al., 1991; Gómez et al., 1997), the lower values of both variables obtained for BNP + $\mathrm{BP}$ cheese would be beneficial for flavor quality. Distinct peptide profiles for cheese manufactured with or without a BP adjunct, with a lower proportion of hydrophobic peptides in the cheese made with $\mathrm{BP}$, were obtained by Morgan et al. (1997). Also, lower content of hydrophobic peptides and a lower hydrophobic:hydrophilic ratio 
Table 7. Hydrophilic and hydrophobic peptides (arbitrary units) determined at $214 \mathrm{~nm}$, and the hydrophobic:hydrophilic ratio in Hispánico cheese manufactured with lacticin 481-producing (BP) Lactococcus lactis ssp. lactis INIA 639, bacteriocin-nonproducing (BNP) L. lactis ssp. lactis INIA 437, and a Lactobacillus helveticus culture (LH) ${ }^{1}$

\begin{tabular}{lccc}
\hline & \multicolumn{3}{c}{ Experimental cheeses $^{2}$} \\
\cline { 2 - 4 } Age & $\mathrm{BNP}+\mathrm{LH}$ & $\mathrm{BNP}+\mathrm{BP}+\mathrm{LH}$ & $\mathrm{BP}+\mathrm{LH}$ \\
\hline Hydrophobic & & & \\
$\quad$ 25 d & $78.9 \pm 8.0^{\mathrm{c}}$ & $57.1 \pm 4.1^{\mathrm{a}}$ & $63.3 \pm 1.2^{\mathrm{b}}$ \\
$50 \mathrm{~d}$ & $74.5 \pm 15.6^{\mathrm{c}}$ & $35.0 \pm 6.8^{\mathrm{a}}$ & $60.8 \pm 0.9^{\mathrm{b}}$ \\
Hydrophilic & & & \\
25 d & $124.6 \pm 4.4^{\mathrm{c}}$ & $113.4 \pm 2.4^{\mathrm{a}}$ & $119.4 \pm 3.0^{\mathrm{b}}$ \\
$50 \mathrm{~d}$ & $156.5 \pm 15.6^{\mathrm{c}}$ & $117.3 \pm 3.7^{\mathrm{a}}$ & $138.6 \pm 8.9^{\mathrm{b}}$ \\
Ratio & & & \\
$25 \mathrm{~d}$ & $0.63 \pm 0.04^{\mathrm{c}}$ & $0.50 \pm 0.03^{\mathrm{a}}$ & $0.53 \pm 0.01^{\mathrm{b}}$ \\
$50 \mathrm{~d}$ & $0.46 \pm 0.05^{\mathrm{b}}$ & $0.29 \pm 0.05^{\mathrm{a}}$ & $0.44 \pm 0.03^{\mathrm{b}}$ \\
\hline
\end{tabular}

${ }^{\mathrm{a}-\mathrm{c}}$ Means in the same row with the same superscript do not differ $(P<0.05)$.

${ }^{1}$ Mean \pm SE $(n=4)$ of duplicate determinations on 2 cheese-making experiments.

${ }^{2}$ Cheeses: $\mathrm{BNP}+\mathrm{LH}=5 \mathrm{~mL} / \mathrm{L}$ of bacteriocin-nonproducing $L$. lactis ssp. lactis INIA 437, and $5 \mathrm{~mL} / \mathrm{L}$ of a Lactobacillus helveticus culture; $\mathrm{BNP}+\mathrm{BP}+\mathrm{LH}=2.5 \mathrm{~mL} / \mathrm{L}$ of bacteriocin-nonproducing L. lactis $\mathrm{ssp}$. lactis INIA 437, $2.5 \mathrm{~mL} / \mathrm{L}$ of lacticin 481-producing Lactococcus lactis ssp. lactis INIA 639 , and $5 \mathrm{~mL} / \mathrm{L}$ of a Lactobacillus helveticus culture; $\mathrm{BP}+\mathrm{LH}=5 \mathrm{~mL} / \mathrm{L}$ of a lacticin 481-producing Lactococcus lactis ssp. lactis INIA 639 , and $5 \mathrm{~mL} / \mathrm{L}$ of a Lactobacillus helveticus culture.

were achieved by Garde et al. (2002a) and Ávila et al. (2005a), when BP adjuncts were added together with the starter culture. Higher levels of hydrophilic peptides and a lower hydrophobic:hydrophilic ratio were found in Cheddar cheese made with $L b$. casei and a nisin $\mathrm{Z}$ producer (Benech et al., 2003). In those studies, the lower levels of hydrophobic peptides in experimental cheese were related to the release of intracellular peptidases when the bacteriocins induced the lysis of starter bacteria. More extensive peptide hydrolysis was recorded in cheese made with an autolytic $L b$. helveticus strain than in cheese made with a nonautolytic $L b$. helveticus strain (Valence et al., 2000).

Free amino acids increased significantly $(P<0.001)$ with cheese age (Tables 8 and 9 ). The BNP + BP cheese showed the highest levels of free amino acids, followed by BP cheese. Levels of total free amino acids in BNP $+\mathrm{BP}$ cheese on $\mathrm{d} 25$ and 50 were 2.4- and 2.1-fold higher than the respective values in BNP cheese (Tables 8 and 9). After $50 \mathrm{~d}$, the highest increases in individual free amino acids in $\mathrm{BNP}+\mathrm{BP}$ cheese with respect to $\mathrm{BNP}$ cheese were recorded for Ile, His, Glu, and Val (Table 9). Cysteine was not detected in any cheese throughout the ripening period. Higher levels of free amino acids in cheeses made with a BP culture have been previously reported (Morgan et al., 1997; Garde et al., 2002a; Sallami et al., 2004a; Ávila et al., 2005a). The high levels of free amino acids in BNP + BP cheese can be explained by a more rapid breakdown of the peptides originating
Table 8. Free amino acids (mg/g of DM) in 25-d-old Hispánico cheese manufactured with lacticin 481-producing (BP) Lactococcus lactis ssp. lactis INIA 639, bacteriocin-nonproducing (BNP) L. lactis ssp. lactis INIA 437, and a Lactobacillus helveticus culture (LH) ${ }^{1}$

\begin{tabular}{lccc}
\hline & \multicolumn{3}{c}{ Experimental cheeses $^{2}$} \\
\cline { 2 - 4 } Amino acid & BNP $+\mathrm{LH}$ & $\mathrm{BNP}+\mathrm{BP}+\mathrm{LH}$ & $\mathrm{BP}+\mathrm{LH}$ \\
\hline Asp & $0.18 \pm 0.02^{\mathrm{a}}$ & $0.41 \pm 0.03^{\mathrm{c}}$ & $0.30 \pm 0.03^{\mathrm{b}}$ \\
Ser & $0.65 \pm 0.14^{\mathrm{a}}$ & $1.88 \pm 0.23^{\mathrm{c}}$ & $1.59 \pm 0.16^{\mathrm{b}}$ \\
Glu & $0.69 \pm 0.12^{\mathrm{a}}$ & $2.77 \pm 0.25^{\mathrm{b}}$ & $2.73 \pm 0.13^{\mathrm{b}}$ \\
Gly & $0.13 \pm 0.05^{\mathrm{a}}$ & $0.49 \pm 0.05^{\mathrm{c}}$ & $0.38 \pm 0.04^{\mathrm{b}}$ \\
His & $0.84 \pm 0.19^{\mathrm{a}}$ & $3.53 \pm 0.43^{\mathrm{c}}$ & $2.67 \pm 0.27^{\mathrm{b}}$ \\
Arg & $\mathrm{ND}^{\mathrm{a}}$ & $0.06 \pm 0.03^{\mathrm{b}}$ & $1.06 \pm 0.21^{\mathrm{c}}$ \\
Thr & $0.40 \pm 0.03^{\mathrm{a}}$ & $0.88 \pm 0.02^{\mathrm{c}}$ & $0.67 \pm 0.03^{\mathrm{b}}$ \\
Ala & $0.34 \pm 0.06^{\mathrm{a}}$ & $0.75 \pm 0.07^{\mathrm{c}}$ & $0.63 \pm 0.07^{\mathrm{b}}$ \\
Pro & $3.05 \pm 0.37^{\mathrm{b}}$ & $3.23 \pm 0.48^{\mathrm{c}}$ & $1.65 \pm 0.14^{\mathrm{a}}$ \\
Cys & $\mathrm{ND}^{\mathrm{a}}$ & $\mathrm{ND}^{\mathrm{a}}$ & $\mathrm{ND}^{\mathrm{a}}$ \\
Tyr & $0.30 \pm 0.04^{\mathrm{a}}$ & $0.75 \pm 0.06^{\mathrm{c}}$ & $0.60 \pm 0.04^{\mathrm{b}}$ \\
Val & $0.47 \pm 0.10^{\mathrm{a}}$ & $1.57 \pm 0.16^{\mathrm{c}}$ & $1.21 \pm 0.11^{\mathrm{b}}$ \\
Met & $0.24 \pm 0.03^{\mathrm{a}}$ & $0.52 \pm 0.02^{\mathrm{c}}$ & $0.41 \pm 0.01^{\mathrm{b}}$ \\
Lys & $1.75 \pm 0.24^{\mathrm{a}}$ & $4.41 \pm 0.33^{\mathrm{c}}$ & $3.51 \pm 0.14^{\mathrm{b}}$ \\
Ile & $0.32 \pm 0.04^{\mathrm{a}}$ & $1.05 \pm 0.15^{\mathrm{c}}$ & $0.78 \pm 0.09^{\mathrm{b}}$ \\
Leu & $1.56 \pm 0.22^{\mathrm{a}}$ & $3.76 \pm 0.17^{\mathrm{c}}$ & $3.20 \pm 0.16^{\mathrm{b}}$ \\
Phe & $0.82 \pm 0.05^{\mathrm{a}}$ & $1.86 \pm 0.08^{\mathrm{c}}$ & $1.54 \pm 0.05^{\mathrm{b}}$ \\
Total & $11.73 \pm 1.67^{\mathrm{a}}$ & $27.90 \pm 1.51^{\mathrm{c}}$ & $22.93 \pm 1.64^{\mathrm{b}}$ \\
\hline
\end{tabular}

${ }^{\mathrm{a}-\mathrm{c}}$ Means in the same row with the same superscript do not differ $(P<0.05)$.

${ }^{1}$ Mean \pm SE $(n=4)$ of duplicate determinations on 2 cheese-making experiments. $\mathrm{ND}=$ not detected.

${ }^{2}$ Cheeses: $\mathrm{BNP}+\mathrm{LH}=5 \mathrm{~mL} / \mathrm{L}$ of bacteriocin-nonproducing $L$. lactis ssp. lactis INIA 437, and $5 \mathrm{~mL} / \mathrm{L}$ of a Lactobacillus helveticus culture; $\mathrm{BNP}+\mathrm{BP}+\mathrm{LH}=2.5 \mathrm{~mL} / \mathrm{L}$ of bacteriocin-nonproducing $L$. lactis ssp. lactis INIA 437, $2.5 \mathrm{~mL} / \mathrm{L}$ of lacticin 481-producing Lactococcus lactis ssp. lactis INIA 639, and $5 \mathrm{~mL} / \mathrm{L}$ of a Lactobacillus helveticus culture; $\mathrm{BP}+\mathrm{LH}=5 \mathrm{~mL} / \mathrm{L}$ of a lacticin 481-producing Lactococcus lactis ssp. lactis INIA 639 , and $5 \mathrm{~mL} / \mathrm{L}$ of a Lactobacillus helveticus culture.

from casein when intracellular peptidases are released into the cheese matrix (Wilkinson et al., 1994; Morgan et al., 1997). Higher levels of free amino acids were found in cheese made with an autolytic Lb. helveticus strain than in cheese made with a nonautolytic $L b$. helveticus strain (Valence et al., 2000).

\section{Cheese Texture}

Fracturability, hardness, and elasticity, determined from the compression curves obtained with the Instron tester, increased significantly $(P<0.001)$ during cheese ripening (Table 10), probably because the strengthening effect of moisture loss during ripening predominated over the weakening effect of caseinolysis (Picón et al., 1994). The 3 rheological characteristics were higher in BNP cheese than in cheeses made with BP. Residual $\alpha_{\mathrm{S}}$-casein plays a crucial role in the stability of the cheese protein network (Creamer and Olson, 1982). Degradation of $\alpha_{\mathrm{S}}$-casein was more extensive in BP cheeses than in BNP cheeses (Table 6). A relationship between lower levels of residual $\alpha_{\mathbb{S}^{-}}$-casein in Hispánico cheese and a softer cheese texture has been previously reported (Mohedano et al., 1998; Ávila et al., 2005a). 
Table 9. Free amino acids (mg/g of DM) in 50-d-old Hispánico cheese manufactured with lacticin 481-producing (BP) Lactococcus lactis ssp. lactis INIA 639, bacteriocin-nonproducing (BNP) L. lactis ssp. lactis INIA 437, and a Lactobacillus helveticus culture (LH) ${ }^{1}$

\begin{tabular}{lccc}
\hline & \multicolumn{3}{c}{ Experimental cheeses $^{2}$} \\
\cline { 2 - 4 } Amino acid & BNP $+\mathrm{LH}$ & $\mathrm{BNP}+\mathrm{BP}+\mathrm{LH}$ & $\mathrm{BP}+\mathrm{LH}$ \\
\hline Asp & $0.45 \pm 0.09^{\mathrm{a}}$ & $1.04 \pm 0.20^{\mathrm{c}}$ & $0.75 \pm 0.13^{\mathrm{b}}$ \\
Ser & $1.45 \pm 0.32^{\mathrm{a}}$ & $3.64 \pm 0.54^{\mathrm{c}}$ & $2.86 \pm 0.30^{\mathrm{b}}$ \\
Glu & $1.51 \pm 0.37^{\mathrm{a}}$ & $4.61 \pm 0.74^{\mathrm{b}}$ & $4.52 \pm 0.36^{\mathrm{b}}$ \\
Gly & $0.37 \pm 0.11^{\mathrm{a}}$ & $0.97 \pm 0.13^{\mathrm{c}}$ & $0.76 \pm 0.08^{\mathrm{b}}$ \\
His & $1.96 \pm 0.42^{\mathrm{a}}$ & $6.15 \pm 0.80^{\mathrm{c}}$ & $4.65 \pm 0.43^{\mathrm{b}}$ \\
Arg & $0.13 \pm 0.08^{\mathrm{a}}$ & $0.37 \pm 0.03^{\mathrm{b}}$ & $1.42 \pm 0.06^{\mathrm{c}}$ \\
Thr & $0.71 \pm 0.07^{\mathrm{a}}$ & $1.55 \pm 0.21^{\mathrm{c}}$ & $1.17 \pm 0.05^{\mathrm{b}}$ \\
Ala & $0.58 \pm 0.09^{\mathrm{a}}$ & $1.36 \pm 0.17^{\mathrm{c}}$ & $1.06 \pm 0.07^{\mathrm{b}}$ \\
Pro & $5.05 \pm 0.41^{\mathrm{b}}$ & $5.15 \pm 1.03^{\mathrm{b}}$ & $3.18 \pm 0.31^{\mathrm{a}}$ \\
Cys & $\mathrm{ND}$ & $\mathrm{ND}$ & $\mathrm{ND}$ \\
Tyr & $0.61 \pm 0.11^{\mathrm{a}}$ & $1.60 \pm 0.21^{\mathrm{a}}$ & $1.25 \pm 0.16^{\mathrm{b}}$ \\
Val & $1.05 \pm 0.23^{\mathrm{a}}$ & $3.10 \pm 0.44^{\mathrm{c}}$ & $2.35 \pm 0.27^{\mathrm{b}}$ \\
Met & $0.59 \pm 0.12^{\mathrm{a}}$ & $1.19 \pm 0.21^{\mathrm{c}}$ & $0.87 \pm 0.08^{\mathrm{b}}$ \\
Lys & $3.75 \pm 0.60^{\mathrm{a}}$ & $7.99 \pm 0.94^{\mathrm{c}}$ & $6.53 \pm 0.48^{\mathrm{b}}$ \\
Ile & $0.74 \pm 0.17^{\mathrm{a}}$ & $2.40 \pm 0.43^{\mathrm{c}}$ & $1.71 \pm 0.27^{\mathrm{b}}$ \\
Leu & $3.11 \pm 0.39^{\mathrm{a}}$ & $5.67 \pm 0.48^{\mathrm{c}}$ & $4.95 \pm 0.37^{\mathrm{b}}$ \\
Phe & $1.55 \pm 0.09^{\mathrm{a}}$ & $3.14 \pm 0.32^{\mathrm{c}}$ & $2.54 \pm 0.20^{\mathrm{b}}$ \\
Total & $23.62 \pm 3.65^{\mathrm{a}}$ & $49.94 \pm 4.74^{\mathrm{c}}$ & $40.55 \pm 3.62^{\mathrm{b}}$ \\
\hline
\end{tabular}

${ }^{\mathrm{a}-\mathrm{c}}$ Means in the same row with the same superscript do not differ $(P<0.05)$.

${ }^{1}$ Mean $\pm \mathrm{SE}(\mathrm{n}=4)$ of duplicate determinations on 2 cheese-making experiments. $\mathrm{ND}=$ not detected.

${ }^{2}$ Cheeses: $\mathrm{BNP}+\mathrm{LH}=5 \mathrm{~mL} / \mathrm{L}$ of bacteriocin-nonproducing $L$. lactis ssp. lactis INIA 437, and $5 \mathrm{~mL} / \mathrm{L}$ of a Lactobacillus helveticus culture; $\mathrm{BNP}+\mathrm{BP}+\mathrm{LH}=2.5 \mathrm{~mL} / \mathrm{L}$ of bacteriocin-nonproducing $L$. lactis ssp. lactis INIA 437, $2.5 \mathrm{~mL} / \mathrm{L}$ of lacticin 481-producing Lactococcus lactis ssp. lactis INIA 639, and $5 \mathrm{~mL} / \mathrm{L}$ of a Lactobacillus helveticus culture; $\mathrm{BP}+\mathrm{LH}=5 \mathrm{~mL} / \mathrm{L}$ of a lacticin 481-producing Lactococcus lactis $\mathrm{ssp}$ lactis INIA 639 , and $5 \mathrm{~mL} / \mathrm{L}$ of a Lactobacillus helveticus culture.

Table 10. Textural characteristics of Hispánico cheese manufactured with lacticin 481-producing (BP) Lactococcus lactis ssp. lactis INIA 639, bacteriocin-nonproducing (BNP) L. lactis ssp. lactis INIA 437, and a Lactobacillus helveticus culture $(\mathrm{LH})^{1}$

\begin{tabular}{|c|c|c|c|}
\hline \multirow[b]{2}{*}{ Age } & \multicolumn{3}{|c|}{ Experimental cheeses $^{2}$} \\
\hline & $\mathrm{BNP}+\mathrm{LH}$ & $\begin{array}{l}\mathrm{BNP}+\mathrm{BP} \\
+\mathrm{LH}\end{array}$ & $\mathrm{BP}+\mathrm{LH}$ \\
\hline \multicolumn{4}{|c|}{ Fracturability $(\mathrm{N})$} \\
\hline $25 \mathrm{~d}$ & $22.22 \pm 1.61^{\mathrm{b}}$ & $17.37 \pm 0.51^{\mathrm{a}}$ & $16.50 \pm 0.68$ \\
\hline $50 \mathrm{~d}$ & $36.04 \pm 1.70^{b}$ & $30.73 \pm 2.30^{\mathrm{a}}$ & $28.14 \pm 1.66$ \\
\hline \multicolumn{4}{|c|}{ Hardness (J) } \\
\hline $25 \mathrm{~d}$ & $0.27 \pm 0.02^{\mathrm{b}}$ & $0.22 \pm 0.01^{\mathrm{a}}$ & $0.20 \pm 0.01$ \\
\hline $50 \mathrm{~d}$ & $0.45 \pm 0.02^{\mathrm{b}}$ & $0.42 \pm 0.03^{\mathrm{ab}}$ & $0.39 \pm 0.02$ \\
\hline \multicolumn{4}{|c|}{ Elasticity $\left(\mathrm{N} / \mathrm{mm}^{2}\right)$} \\
\hline $25 \mathrm{~d}$ & $0.57 \pm 0.06^{\mathrm{b}}$ & $0.36 \pm 0.02^{\mathrm{a}}$ & $0.38 \pm 0.02$ \\
\hline $50 \mathrm{~d}$ & $1.51 \pm 0.08^{\mathrm{b}}$ & $1.17 \pm 0.10^{\mathrm{a}}$ & $1.12 \pm 0.06$ \\
\hline
\end{tabular}

${ }^{\mathrm{a}, \mathrm{b}}$ Means in the same row with the same superscript do not differ $(P<0.05)$.

${ }^{1}$ Mean $\pm \mathrm{SE}(\mathrm{n}=12)$ of 6 determinations on 2 cheese-making experiments.

${ }^{2}$ Cheeses: $\mathrm{BNP}+\mathrm{LH}=5 \mathrm{~mL} / \mathrm{L}$ of bacteriocin-nonproducing $L$. lactis ssp. lactis INIA 437, and $5 \mathrm{~mL} / \mathrm{L}$ of a Lactobacillus helveticus culture; $\mathrm{BNP}+\mathrm{BP}+\mathrm{LH}=2.5 \mathrm{~mL} / \mathrm{L}$ of bacteriocin-nonproducing $L$. lactis ssp. lactis INIA 437, $2.5 \mathrm{~mL} / \mathrm{L}$ of lacticin 481-producing Lactococcus lactis ssp. lactis INIA 639 , and $5 \mathrm{~mL} / \mathrm{L}$ of a Lactobacillus helveticus culture; $\mathrm{BP}+\mathrm{LH}=5 \mathrm{~mL} / \mathrm{L}$ of a lacticin 481-producing Lactococcus lactis ssp. lactis INIA 639 , and $5 \mathrm{~mL} / \mathrm{L}$ of a Lactobacillus helveticus culture.
Table 11. Sensory evaluation of Hispánico cheese manufactured with lacticin 481-producing (BP) Lactococcus lactis ssp. lactis INIA 639, bacteriocin-nonproducing (BNP) L. lactis ssp. lactis INIA 437, and a Lactobacillus helveticus culture $(\mathrm{LH})^{1}$

\begin{tabular}{llll}
\hline & \multicolumn{3}{c}{ Experimental cheeses $^{2}$} \\
\cline { 2 - 4 } Age & $\mathrm{BNP}+\mathrm{LH}$ & $\mathrm{BNP}+\mathrm{BP}+\mathrm{LH}$ & $\mathrm{BP}+\mathrm{LH}$ \\
\hline Taste quality & & & \\
$\quad 25 \mathrm{~d}$ & $4.30 \pm 0.27^{\mathrm{a}}$ & $6.28 \pm 0.23^{\mathrm{b}}$ & $5.69 \pm 0.27^{\mathrm{b}}$ \\
$50 \mathrm{~d}$ & $4.01 \pm 0.30^{\mathrm{a}}$ & $6.45 \pm 0.30^{\mathrm{b}}$ & $6.23 \pm 0.31^{\mathrm{b}}$ \\
Taste intensity & & & \\
25 d & $6.02 \pm 0.30^{\mathrm{a}}$ & $6.20 \pm 0.17^{\mathrm{a}}$ & $5.89 \pm 0.25^{\mathrm{a}}$ \\
$50 \mathrm{~d}$ & $6.28 \pm 0.24^{\mathrm{a}}$ & $6.84 \pm 0.24^{\mathrm{a}}$ & $6.75 \pm 0.20^{\mathrm{a}}$ \\
\hline
\end{tabular}

${ }^{\mathrm{a}, \mathrm{b}}$ Means in the same row with the same superscript do not differ $(P<0.05)$.

${ }^{1}$ Mean $\pm \mathrm{SE}(\mathrm{n}=24)$ of scores from 12 trained panelists on 2 cheesemaking experiments using a 10-point scale.

${ }^{2}$ Cheeses: $\mathrm{BNP}+\mathrm{LH}=5 \mathrm{~mL} / \mathrm{L}$ of bacteriocin-nonproducing $L$. lactis ssp. lactis INIA 437 , and $5 \mathrm{~mL} / \mathrm{L}$ of a Lactobacillus helveticus culture; $\mathrm{BNP}+\mathrm{BP}+\mathrm{LH}=2.5 \mathrm{~mL} / \mathrm{L}$ of bacteriocin-nonproducing $L$. lactis $\mathrm{ssp}$. lactis INIA 437, $2.5 \mathrm{~mL} / \mathrm{L}$ of lacticin 481-producing Lactococcus lactis ssp. lactis INIA 639, and $5 \mathrm{~mL} / \mathrm{L}$ of a Lactobacillus helveticus culture; $\mathrm{BP}+\mathrm{LH}=5 \mathrm{~mL} / \mathrm{L}$ of a lacticin 481-producing Lactococcus lactis $\mathrm{ssp}$. lactis INIA 639, and $5 \mathrm{~mL} / \mathrm{L}$ of a Lactobacillus helveticus culture.

\section{Sensory Evaluation}

The type of mesophilic starter used in cheese manufacture significantly $(P<0.05)$ affected taste quality, but not taste intensity (Table 11). Both cheeses made with the BP received higher scores for taste quality than did BNP cheese. Taste intensity increased in all cheeses with age, whereas taste quality increased with age in cheese made with the BP, and decreased in BNP cheese. Our results agree with those reported for Cheddar cheese made with a BP adjunct, which showed higher sensory evaluation scores than control cheese (Morgan et al., 1997). Also, addition of a BP adjunct culture in Hispánico cheese manufacture resulted in significantly higher scores of flavor quality and flavor intensity (Garde et al., 2002a). Higher flavor intensity and flavor quality scores were obtained when a nisinproducing $L$. lactis ssp. lactis strain was combined with a highly autolytic and proteolytic $L b$. delbrueckii ssp. bulgaricus strain for Cheddar cheese manufacture (Sallami et al., 2004b). Similarly, the addition of $L b$. casei and liposome-encapsulated nisin $\mathrm{Z}$ improved flavor intensity and sensory characteristics of Cheddar cheese (Benech et al., 2003).

Scores for Hispánico cheese taste descriptors (data not shown) were (mean values on a 0 to 6 points scale, considering all ages and all vats): 2.45 for sour, 1.66 for bitter, 0.66 for sweet, 1.04 for salty, and 1.25 for umami. Cheese age had no significant $(P<0.05)$ influence on any of these taste attributes. Bitter taste scores were significantly $(P<0.05)$ higher in BNP cheese (2.39) than in BNP + BP cheese (1.22) or in BP cheese (1.38). 


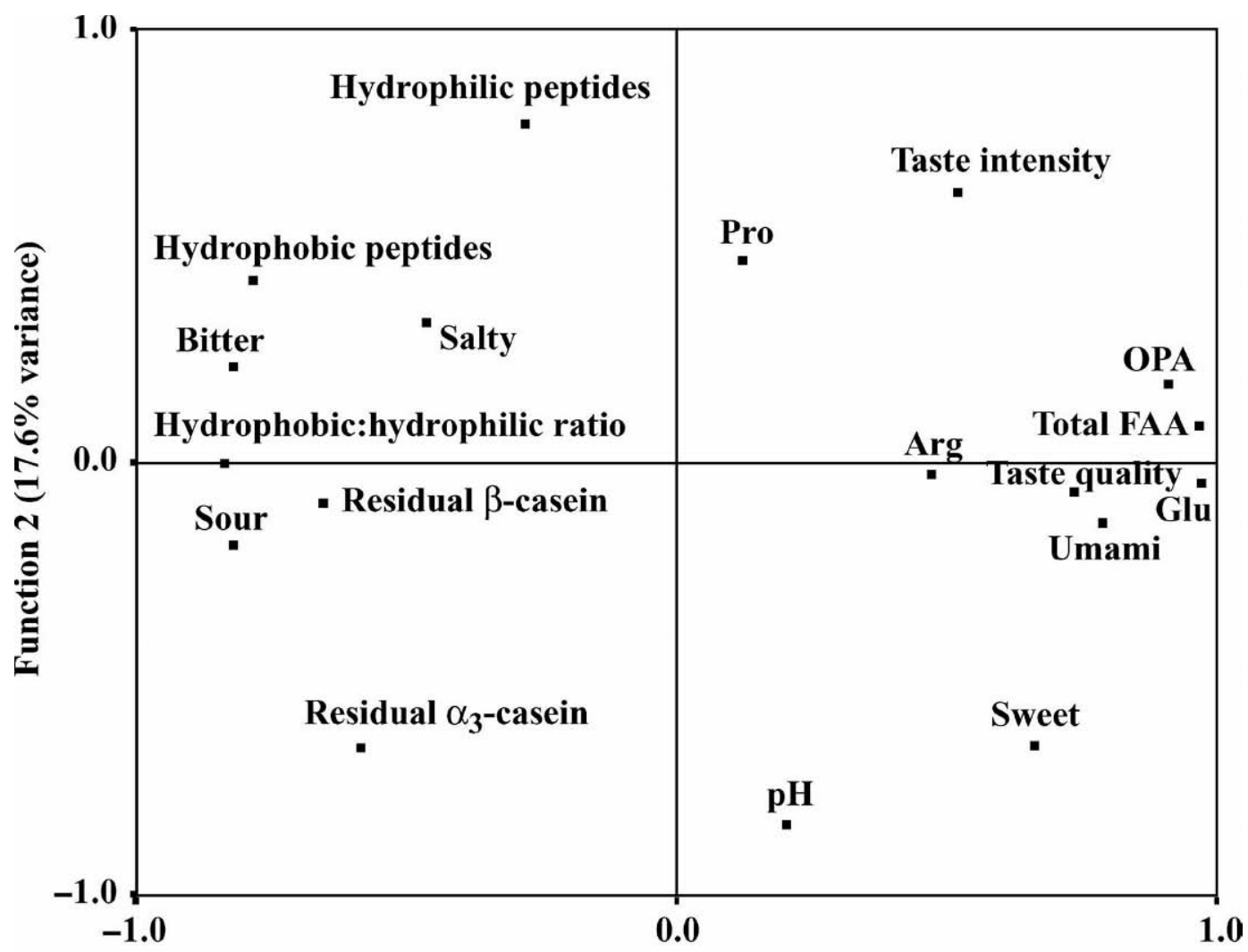

Function 1 (47.9\% variance)

Figure 1. Functions 1 and 2 of principal component analysis with Varimax rotation carried out on pH, proteolysis parameters [caseins, peptides, proteolysis o-phthaldialdehyde (OPA) method, free amino acids], and taste attributes (quality, intensity, and individual descriptors).

The use of BP adjuncts had been reported to reduce cheese bitterness in previous works (Benech et al., 2003; Sallami et al., 2004b). On the other hand, umami taste scores were significantly $(P<0.05)$ higher in BNP + $\mathrm{BP}$ cheese (1.72) or in BP cheese (1.28) than in BNP cheese (0.74).

Principal component analysis with Varimax rotation was carried out to correlate $\mathrm{pH}$ and proteolysis with cheese taste attributes (Figure 1). Functions 1 and 2 explained 47.9 and $17.6 \%$ of the variance, respectively. Total free amino acids, Glu, proteolysis (OPA method), umami taste descriptor, taste quality, sweet taste descriptor, and taste intensity correlated positively with function 1 , whereas hydrophobic:hydrophilic ratio, hydrophobic peptides, residual $\beta$ - and $\alpha_{\mathrm{S}}$-caseins, and bitter taste and sour taste descriptors correlated negatively with function 1 . Hydrophilic peptides and taste intensity correlated positively with function 2 , whereas $\mathrm{pH}$, residual $\alpha$ s-casein, and sweet taste descriptor correlated negatively with function 2 .

\section{CONCLUSIONS}

From the results obtained in the present work, it may be concluded that the combination of bacteriocinproducing $L$. lactis ssp. lactis INIA 639, bacteriocinnonproducing $L$. lactis ssp. lactis INIA 437, and a $L b$. helveticus culture as lactic starter optimized the release of intracellular aminopeptidases during early cheese ripening. A more rapid evolution of proteolysis and higher quality of taste, with a reduction in bitterness scores, were achieved by the combined use of the 3 cultures. The procedure here presented seems a simple and inexpensive method for the acceleration of cheese ripening, with no concomitant risks of bitter flavor defect.

\section{ACKNOWLEDGMENTS}

The authors acknowledge financial support from projects AGL 2000-1426 and RTA 01-044, the INIA grant 
to Marta Ávila, and valuable technical assistance from B. Rodríguez and M. De Paz.

\section{REFERENCES}

AOAC. 1990. Official Methods of Analysis. Vol. II. 15th ed. Association of Official Analytical Chemists, Arlington, VA.

Ávila, M., S. Garde, P. Gaya, M. Medina, and M. Nuñez. 2005a. Influence of a bacteriocin-producing lactic culture on proteolysis and texture of Hispánico cheese. Int. Dairy J. 15:145-153.

Ávila, M., S. Garde, M. Medina, and M. Nuñez. 2005b. The effect of milk inoculation with bacteriocin-producing lactic acid bacteria on a Lactobacillus helveticus adjunct cheese culture. J. Food Prot. 68:1026-1033.

Benech, R. O., E. E. Kheadr, C. Lacroix, and I. Fliss. 2003. Impact of nisin producing culture and liposome-encapsulated nisin on ripening of Lactobacillus added-Cheddar cheese. J. Dairy Sci. 86:1895-1909

Bérodier, F., P. Lavanchy, M. Zannoni, J. Casals, L. Herrero, and C. Aramo. 1997. A guide to the sensory evaluation of smell, aroma and taste of hard and semi-hard cheeses. Lebensm. Wiss. Technol. 30:653-664.

Cohen, S. A., and D. P. Michaud. 1993. Synthesis of a fluorescent derivatizing reagent, 6-aminoquinolyl-N-hydroxysuccinimidyl carbamate, and its application for the analysis of hydrolysate amino acids in high-performance liquid chromatography. Anal. Biochem. 211:279-287.

Creamer, L. K., and N. F. Olson. 1982. Rheological evaluation of maturing Cheddar cheese. J. Food Sci. 47:631-636.

Church, F. C., H. E. Swaisgood, D. H. Porter, and G. L. Catignani. 1983. Spectrophotometric assay using $o$-phthaldialdehyde for determination of proteolysis in milk and isolated milk proteins. J. Dairy Sci. 66:1219-1227.

Fox, P. F., J. M. Wallace, S. Morgan, C. M. Lynch, E. J. Niland, and J. Tobin. 1996. Acceleration of cheese ripening. Antonie Leeuwenhoek Int. J. Gen. Microbiol. 70:271-297.

Garde, S., M. Carbonell, E. Fernández-García, M. Medina, and M. Nuñez. 2002b. Volatile compounds in Hispánico cheese manufactured using a mesophilic starter, a thermophilic adjunct culture, and a bacteriocin-producing Lactococcus lactis subsp. lactis INIA 415. J. Agric. Food Chem. 50:6752-6757.

Garde, S., P. Gaya, M. Medina, and M. Nuñez. 1997. Acceleration of flavour formation in cheese by a bacteriocin-producing adjunct lactic culture. Biotechnol. Lett. 19:1011-1014.

Garde, S., J. Tomillo, P. Gaya, M. Medina, and M. Nuñez. 2002a. Proteolysis in Hispánico cheese manufactured using a mesophilic starter, a thermophilic adjunct culture and bacteriocin-producing Lactococcus lactis subsp. lactis INIA 415 adjunct culture. J. Agric. Food Chem. 50:3479-3485.

Gaya, P., M. Medina, M. A. Rodríguez-Marín, and M. Nuñez. 1990 Accelerated ripening of ewes' milk Manchego cheese: The effect of elevated ripening temperatures. J. Dairy Sci. 73:26-32.

Gómez, M. J., S. Garde, P. Gaya, M. Medina, and M. Nuñez. 1997. Relationship between levels of hydrophobic peptides and bitter- ness in cheese made from pasteurized and raw milk. J. Dairy Res. 64:289-297.

Hanon, J. A., M. G. Wilkinson, C. M. Delahunty, J. M. Wallace, P. A. Morrissey, and T. P. Beresford. 2003. Use of autolytic starter systems to accelerate the ripening of Cheddar cheese. Int. Dairy J. 13:313-323.

Hickey, M. W., A. J. Hillier, and G. R. Jago. 1983. Enzymic activities associated with lactobacilli in dairy products. Aust. J. Dairy Technol. 38:154-157.

Krause, I., A. Bockhardt, H. Neckermann, T. Henle, and H. Klostermeyer. 1995. Simultaneous determination of amino acids and biogenic amines by reversed-phase high-performance liquid chromatography of the dabsyl derivatives. J. Chromatogr. A 715:67-79.

Lau, K. Y., D. M. Barbano, and R. R. Rasmussen. 1991. Influence of pasteurization of milk on protein breakdown in Cheddar cheese during aging. J. Dairy Sci. 74:727-740.

Martínez-Cuesta, M. C., T. Requena, and C. Peláez. 2001. Use of a bacteriocin-producing transconjugant as starter in acceleration of cheese ripening. Int. J. Food Microbiol. 70:79-88.

Mohedano, A. F., J. Fernández, P. Gaya, M. Medina, and M. Nuñez. 1998. Effect of the cysteine proteinase from Micrococcus spp. INIA 528 on the ripening process of Hispanico cheese. J. Dairy Res. 65:621-630.

Morgan, S., R. P. Ross, and C. Hill. 1997. Increasing starter cell lysis in Cheddar cheese using a bacteriocin-producing adjunct. J. Dairy Sci. 80:1-10.

Morgan, S., R. P. Ross, and C. Hill. 1995. Bacteriolytic activity caused by the presence of a novel lactococcal plasmid encoding lactococcins A, B and M. Appl. Environ. Microbiol. 61:2995-3001.

O'Sullivan, L. O., S. M. Morgan, R. P. Ross, and C. Hill. 2002. Elevated enzyme release from lactococcal starter cultures on exposure to the lantibiotic lacticin 481, produced by Lactococcus lactis DPC5552. J. Dairy Sci. 85:2130-2140.

Picón, A., P. Gaya, M. Medina, and M. Nuñez. 1994. The effect of liposome encapsulation of chymosin derived by fermentation on Manchego cheese ripening. J. Dairy Sci. 77:16-23.

Recio, I., M. Ramos, and L. Amigo. 1997. Study of the polymorphism of ovine $\alpha \mathrm{s} 1$ - and $\alpha \mathrm{s} 2$-caseins by capillary electrophoresis. J. Dairy Res. 64:525-534.

Sallami, L., E. E. Kheadr, I. Fliss, and J. C. Vuillemard. 2004a. Impact of autolytic, proteolytic, and nisin-producing adjunct cultures on biochemical and textural properties of Cheddar cheese. J. Dairy Sci. 87:1585-1594.

Sallami, L., E. E. Kheadr, I. Fliss, and J. C. Vuillemard. 2004b. Impact of autolytic and proteolytic lactobacilli and nisin-producing culture on proteolysis and sensory characteristics in Cheddar cheese. J. Food Sci. 69: FCT24-32.

Sasaki, M., B. W. Bosman, and P. S. T. Tan. 1995. Comparison of proteolytic activities in various lactobacilli. J. Dairy Res. 62:601-610.

Valence, F., S. M. Deutsch, R. Richoux, V. Gagnaire, and S. Lortal. 2000. Autolysis and related proteolysis in Swiss cheese for two Lactobacillus helveticus strains. J. Dairy Res. 67:261-271.

Wilkinson, M. G., T. P. Guinee, D. M. O'Callaghan, and P. F. Fox. 1994. Autolysis and proteolysis in different strains of starter bacteria during Cheddar cheese ripening. J. Dairy Res. 61:249-262. 